Bangl. J. Vet. Med. (2010). 8(1): $11-16$

\title{
PREVALENCE OF SUBCLINICAL GASTRO-INTESTINAL PARASITOSIS AND THEIR EFFECTS ON MILK PRODUCTION WITH THERAPEUTIC MANAGEMENT IN RED CHITTAGONG CATTLE
}

\author{
M. M. Rahman* and M. A. Samad \\ Department of Medicine, Faculty of Veterinary Science, Bangladesh Agricultural University, \\ Mymensingh-2202, Bangladesh; e-mail: masamad88bau@yahoo.com
}

\begin{abstract}
The prevalence of sub-clinical gastro-intestinal parasitosis and their effects on health and milk production with therapeutic management were studied in 87 Red Chittagong cattle (RCC) reared at the Bangladesh Agricultural University Dairy Farm (BAUDF), Mymensingh during the period from March to July 2008. Of the 87 RCC aged between 1 to 96 months which included 22 milch cows, 15 pregnant cows, 8 dry cows, 18 weaned calves and 24 unweaned calves. Parasitological examination of faecal samples of all the selected 87 RCC showed that $51.72 \%(n=45)$ animals affected with different types of gastro-intestinal parasites, of which $37.93 \%$ had single, $12.64 \%$ had dual and only $1.15 \%$ animals had triple types of infection. An overall $34.48 \%$ paramphistomiasis, $25.29 \%$ balantidiasis, $2.30 \%$ toxocariasis, $2.30 \%$ strongyloidiasis, $1.15 \%$ trichuriasis and $1.15 \%$ fascioliasis was recorded in RCC. However, toxocariasis (18.75\%), strongyloidiasis (18.75\%) and trichuriasis (6.25\%) were recorded in calves up to 6 months old, and paramphistomiasis (34.48\%) and fascioliasis (1.15\%) in cattle more than 6 months of age whereas balantidiasis (25.29\%) was recorded in all age groups of cattle. The anthelmintic efficacy of the combined commercial preparations with Tetramisole hydrochloride 2.0g and Oxyclozanide 1.4g per bolus (Levanid ${ }^{\circledR}$, Acme ; Tetranid $^{\circledR}$, Techno Drugs) @ 1 bolus / 100 kg body weight with a single oral dose caused 100\% reduction of faecal egg count at day 7 post-treatment. A single oral dose of 1\% copper sulfate solution @ $10 \mathrm{ml} / \mathrm{kg}$ and metranidazole (Flagyl ${ }^{\circledR}$, Aventis) @ $4 \mathrm{mg} / \mathrm{kg}$ body weight resulted $100 \%$ and $42.85 \%$ reduction of Balantidium coli trophozoites, respectively. The average milk production records of RCC affected with gastro-intestinal parasitosis (1.41litre / day / animal) were compared with the mean milk production records at day 7 post-anthelmintic treatment (1.73 liter / day / animal) and results showed an average increased milk yield +0.32 litre / day / animal. This study indicates that RCC affected with sub-clinical gastro-intestinal parasitosis caused ill-health and decrease milk yield like zebu and cross-bred cattle. It may be concluded from this study that the RCC should be regularly monitored through faecal examination for the presence of gastro-intestinal parasites in order to provide rational treatment and control management to make the RCC farming profitable.
\end{abstract}

Keywords: Sub-clinical, Parasitosis, Red Chittagong cattle, milk production, anthelmintic efficacy

\section{INTRODUCTION}

Gastro-intestinal parasitosis adversely affect the nutritional status of the hosts and associated with economic losses in terms of lowered fertility, reduced work capacity, involuntary culling, retarded weight gains, lowered milk production, treatment costs and mortality in heavily parasitized animals (Fikru et al., 2006). Hann and Bekure (1991) estimated annual losses of US \$ 2 billion due to mortality and decreased production in animals caused by endoparasites in Sub-Sahran Africa. The agro-ecological and geo-climatic conditions are favourable for high prevalence of helminthiasis in Bangladesh (Samad, 2000, 2001). The Red Chittagong cattle (RCC) are the only recognized cattle variety available in Bangladesh. But very limited research works on production (Habib et al., 2009; Mufti et al., 2009; Rabeya et al., 2009) and health especially on bovine tuberculosis (Rahman and Samad, 2008) and effects of endoparasites on blood values (Siddiki et al., 2010) have been done in this variety of cattle. This study describes the prevalence of sub-clinical gastro-intestinal parasitosis and their effects on milk production with therapeutic management in RCC maintained under farming system.

*Part of MS research 


\section{M. Rahman and M. A. Samad}

\section{MATERIALS AND METHODS}

This study was carried out for a period of five months, from March to July 2008 at the Bangladesh Agricultural University Dairy Farm (BAUDF), Mymensingh. A total of 87 Red Chittagong cattle (RCC) of either sex (22 lactating cows, 15 pregnant cows, 8 dry cows, 18 weaned calves and 24 unweaned calves), aged between 1 to 96 months reared at the BAUDF under a research project were used as experimental animals for this study.

Faecal samples from each of the 87 selected RCC were collected directly from the rectum in polythene bag and brought to the laboratory of the Department of Medicine, BAU, Mymensingh for parasitological examination. These faecal samples were processed and examined in the laboratory by using direct faecal smear and simple sedimentation methods described by Samad (2008). The parasites were identified under the microscope according to their morphological characteristics (Soulsby, 1986; Samad, 2008). Positive faecal samples were further subjected for counting the number of eggs per gram (epg) of faeces for anthelmintic trial study by using the Stoll's egg counting method as described by Samad (2008).

\section{Milk production record}

Milk production records of each of the gastro-intestinal negative cows $(n=6)$ and parasite affected cows $(n=$ 15) were collected before administration of anthelmintics and at day 7 post-treatment to evaluate the effects of parasites and benefit of treatment on milk production.

\section{Anthelmintic efficacy}

Anthelmintic efficacy was conducted on three groups of animals affected with different types of endoparasites which included paramphistomiasis $(n=30)$ and balantidiosis $(n=15)$ in milch cows and nematodiasis $(n=6)$ in calves under 6 months of age (Table 2). Paraphistomiasis affected animals were divided into two treatment groups, viz. group A $(n=18)$ treated with Levanid ${ }^{\circledR}\left(\right.$ Acme) and group B $(n=12)$ treated with Tetranid ${ }^{\circledR}$ (Techno Drugs). Balantidiosis affected cattle were also divided into two treatment groups, which included group $\mathrm{A}$ ( $\mathrm{n}=$ 11 ) and group $B(n=4)$. Each of the animal of group A and group B was treated with a single oral dose of copper sulfate 1\% solution @ $10 \mathrm{ml} / \mathrm{kg}$ body weight and metranidazole (Flagyl ${ }^{\circledR}$, Aventis) @ $4 \mathrm{mg} / \mathrm{kg}$ body weight, respectively. Egg per gram (epg) of faeces was counted in each of the experimental animals of both the groups before administration of drugs and at day 7 post-treatment. A group of 6 calves below 6 months of age affected with nematodiasis was treated with a single oral dose of Fenbendazole (Peraclear ${ }^{\circledR}$, Techno Drugs) @ $7.5 \mathrm{mg} / \mathrm{kg}$ body weight.

\section{Statistical analysis}

Results were processed using Microsoft Excel 2000 and mean values and standard deviation (SD) were determined. Results were analysed by using $\mathrm{X}^{2}$ and Student's 't'-test for significance (Steel and Torrie, 1980).

\section{RESULTS AND DISCUSSION}

The Red Chittagong cattle (RCC) is one of the recognized varieties of cattle in Bangladesh. Recently an attention has been made on this variety of cattle through establishment of different research projects at national levels for its development and proper utilization in the livestock industry in Bangladesh. Accordingly, this study was conducted on the prevalence of gastro-intestinal parasitosis and their effects on health and milk production and therapeutic management of parasitosis in RCC.

\section{Prevalence of gastro-intestinal parasitosis}

Parasitological examination of faecal samples of 87 RCC showed that $51.72 \%$ animals had infection with different types of gastro-intestinal parasites (Table 1). The $51.72 \%$ prevalence of gastro-intestinal parasitosis recorded in RCC reared under farming system supports the earlier report of Siddiki et al. (2010) who reported $53.16 \%$ prevalence rate of gastro-intestinal parasitosis in RCC maintained under rural condition. 
Parasitosis and milk production in Red Chittagong cattle

Table 1. Prevalence of gastro-intestinal parasitosis in Red Chittagong cattle reared under farming system

\begin{tabular}{|c|c|c|c|c|}
\hline \multicolumn{2}{|c|}{ Single and concomitant diseases $(n=87)$} & \multicolumn{3}{|c|}{ Age-wise prevalence of parasitic diseases } \\
\hline \multirow[t]{2}{*}{ Name of diseases } & Positive & \multirow{2}{*}{$\begin{array}{l}\text { Age } \\
\text { (months) }\end{array}$} & \multirow[t]{2}{*}{ Name of diseases } & \multirow{2}{*}{$\begin{array}{l}\text { Positive } \\
\text { No. (\%) }\end{array}$} \\
\hline & No. (\%) & & & \\
\hline Paramphistomiasis & $20(22.98)$ & $>1$ to 6 & Toxocariasis & $03(18.75)$ \\
\hline Balantidiasis & $11(12.64)$ & $(n=16)$ & Trichuriasis & $01(06.25)$ \\
\hline Toxocariasis & $01(01.15)$ & & Balantidiosis + Strongyloidosis & $03(18.75)$ \\
\hline Strongyloidosis & $01(01.15)$ & & Sub-total: & 07 (43.75) \\
\hline \multirow[t]{2}{*}{ Sub-total (Single): } & $33(37.93)$ & & & \\
\hline & & $>6$ to 12 & Paramphistomiasis & $02(18.18)$ \\
\hline Paramphistomiasis + Balantidiasis & $08(09.19)$ & $(\mathrm{n}=11)$ & Balantidiosis & $01(09.09)$ \\
\hline Balantidiosis + Strongyloidosis & $01(01.15)$ & & Paramphistomiasis + Balantidiasis & $02(18.18)$ \\
\hline Balantidiasis + Trichuriasis & $01(01.15)$ & & Sub-total: & 05 (45.45) \\
\hline Toxocariasis + Paramphistomiasis & $01(01.15)$ & & & \\
\hline \multirow{2}{*}{ Sub-total (Dual): } & $11(12.64)$ & $>12$ to 24 & Paramphistomiasis & $02(20.00)$ \\
\hline & & $(\mathrm{n}=10)$ & Balantidiosis & $01(10.00)$ \\
\hline \multicolumn{2}{|l|}{ Paramphistomiasis + Balantidiasis } & & Paramphistomiasis + Balantidiasis & $01(10.00)$ \\
\hline + Fascioliasis & $01(01.15)$ & & Sub-total: & $04(40.00$ \\
\hline \multirow[t]{2}{*}{ Sub-total (Triple): } & $01(01.15)$ & & & \\
\hline & & $>24$ to 60 & Paramphistomiasis & $07(40.00)$ \\
\hline Paramphistomiasis & $30(34.48)$ & $(\mathrm{n}=28)$ & Balantidiosis & $03(10.71)$ \\
\hline Balantidiosis & $22(25.29)$ & & Paramphistomiasis + Balantidiasis & $05(17.86)$ \\
\hline Toxocariasis & $02(02.30)$ & & Sub-total: & $15(53.57)$ \\
\hline Strongyloidosis & $02(02.30)$ & & & \\
\hline Trichuriasis & $01(01.15)$ & $>60$ to 96 & Paramphistomiasis & $04(18.18)$ \\
\hline Fascioliasis & $01(01.15)$ & $(\mathrm{n}=22)$ & Balantidiosis & $03(13.64)$ \\
\hline \multirow[t]{2}{*}{ Individual disease prevalence: } & & & Paramphistomiasis + Balantidiasis & $06(27.27)$ \\
\hline & & & $\begin{array}{l}\text { Paramphistomiasis + Balantidiasis } \\
+ \text { Fascioliasis }\end{array}$ & 01 (04.55) \\
\hline Overall & $45(51.72)$ & & & $45(51.72)$ \\
\hline
\end{tabular}

$\mathrm{n}=$ No. of cattle examined.

Analysis of the results on the basis of single and concomitant diseases revealed that $37.93 \%$ animals had single, $12.64 \%$ animals had dual and only $1.15 \%$ animals had triple types of endoparasitic infections. This study recorded (34.48\%) prevalence of paramphistomiasis caused by Paramphistomum spp., 25.29\% balantidiasis caused by Balantidium coli, $2.30 \%$ toxoascariasis caused by Toxocara vitulorum, $2.30 \%$ strongyloidiasis caused by Strongyloides papillosus, $1.15 \%$ trichuriasis caused by Trichuris globulosa and $1.15 \%$ fascioliasis caused by Fasciola gigantica in RCC maintained under farming system. The prevalence of $34.48 \%$ paramphistomiasis and $1.15 \%$ fascioliasis recorded in this study in RCC supports the findings of Siddiki et al. (2010) who reported 38\% prevalence of paramphistomiasis and 2\% fascioliasis in RCC. In addition Siddiki et al. (2010) recorded coccidiosis under rural management system whereas it was not recorded in this study but toxocariasis, strongyloidiasis and truchuriasis were recorded in calves in this study. This difference on the prevalence of endoparasitosis might be due to different management systems and regions of investigation. 


\section{M. Rahman and M. A. Samad}

Age-wise prevalence of single and mixed parasitosis in RCC is presented in Table 1. It appears from this Table 1 that the prevalence of toxocariasis (18.75\%), strongyloidiasis (18.75\%) and trichuriasis $(6.25 \%)$ were limited only in calves up to 6 months of age but balantidiasis was recorded in all age groups of cattle. These observations support the earlier reports of Nooruddin et al. (1987), Samad (2000; 2001).

\section{Anthelmintic efficacy}

The anthelmintic efficacy with two available commercial flukicides containing oxyclozanide against paramphistomiasis, copper sulfate and metranidazole against balantidiasis and fenbendazole against nematodiasis were evaluated on the basis of reduction of egg per gram (epg) of faeces.

\section{Anthelmintic trial against paramphistomiasis}

The anathematic trial with combined (Tetramisole hydrochloride $2 \mathrm{~g}+$ Oxyclozanide $1.4 \mathrm{~g}$ ) two commercial preparations (Levanid ${ }^{\circledR}$, Acme) and Tetranid ${ }^{\circledR}$, Techno Drugs) were evaluated against paramphistomiasis in RCC. Treatment of paramphistomiasis with Levanid ${ }^{\circledR}$ (Acme) and Tetranid ${ }^{\circledR}$ (Techno Drugs) showed 100\% reduction of faecal egg count (epg) at day 7 post-treatment (Table 2). This $100 \%$ reduction of faecal egg count might be due to oxyclozanide component of these two drugs (Georgiev and Gruev, 1979; Islam and Samad, 1989; Samad, 2008).

Table 2. Anthelmintic efficacy against gastro-intestinal parasitosis in Red Chittagong cattle

\begin{tabular}{|c|c|c|c|c|c|c|c|}
\hline \multirow[t]{2}{*}{$\mathrm{S} / \mathrm{N}$} & \multirow[t]{2}{*}{ Parasitosis } & \multirow[t]{2}{*}{ Treated with* } & \multirow{2}{*}{$\begin{array}{l}\text { No. of } \\
\text { animals } \\
\text { treated }\end{array}$} & \multirow{2}{*}{$\begin{array}{l}\text { Single oral } \\
\text { dose (mg/kg) } \\
\text { body weight }\end{array}$} & \multicolumn{3}{|c|}{ EPG of faeces (Range \& Mean \pm SD) } \\
\hline & & & & & Pre-treatment & $\begin{array}{l}\text { Post-treatment Effi } \\
\text { after } 7 \text { days }\end{array}$ & $\begin{array}{c}\text { cacy } \\
(\%)\end{array}$ \\
\hline \multirow[t]{2}{*}{ (1) } & $\begin{array}{l}\text { Paramphis- } \\
\text { tomiasis }\end{array}$ & $\begin{array}{l}\text { Levanid }^{\circledR} \\
\text { (Acme) }\end{array}$ & 18 & 18.7 & $\begin{array}{l}100-500 \\
212.5 \pm 145.77\end{array}$ & 0 & 100 \\
\hline & & $\begin{array}{l}\text { Tetranid }^{\circledR} \\
\text { (Techno Drugs) }\end{array}$ & 12 & 18.7 & $\begin{array}{l}100-800 \\
325 \pm 205.04\end{array}$ & 0 & 100 \\
\hline \multirow[t]{2}{*}{ (2) } & Balantidiasis & $\begin{array}{l}\text { Copper sulfate } \\
1 \% \text { solution }\end{array}$ & 11 & $10 \mathrm{ml}$ & $\begin{array}{l}100-500 \\
309.09 \pm 157.82\end{array}$ & 0 & 100 \\
\hline & & $\begin{array}{l}\text { Flagyl }^{\circledR} \\
\text { (Aventis) }\end{array}$ & 04 & $\begin{array}{l}4.0 \text { once daily } \\
\text { for 3days. }\end{array}$ & $\begin{array}{l}400-900 \\
700 \pm 216.02\end{array}$ & $\begin{array}{l}300-500 \\
400 \pm 81.64\end{array}$ & 42.85 \\
\hline (3) & Nematodiasis & $\begin{array}{l}\text { Peraclear }^{\circledR} \\
\text { (Techno Drugs) }\end{array}$ & 06 & 7.5 & $\begin{array}{l}200-1200 \\
516.67 \pm 354.49\end{array}$ & 0 & 100 \\
\hline
\end{tabular}

*Each Levanid ${ }^{\circledR}$ \& Teranid $^{\circledR}$ bolus contains Tetramisole hydrochloride 2.0g + Oxyclozanide 1.4g ; Each Flagyl ${ }^{\circledR}$ tablet contains 400 mg Metranidazole and Each Peraclear ${ }^{\circledR}$ tablet contains 250 mg Fenbendazole.

\section{Treatment trials against balantidiasis}

Copper sulfate 1\% solution@ @ 10 ml / kg body weight and metranidazole (Flagyl ${ }^{\circledR}$, Aventis) @ 4 mg / kg body weight at a single oral dose were evaluated against balantidiasis in RCC. Treatment with copper sulfate solution showed $100 \%$ and with metranidazole showed $42.85 \%$ reduction of $B$. coli trophozoites in the faecal samples (Table 2). The results on the efficacy of copper sulfate solution against bovine balantidiasis are in conformity with the earlier reports of Alam et al. (1979) and Huque et al. (1998) who reported 100\% efficacy in zebu and cross-bred cattle. The $42.85 \%$ efficacy of metranidazole against bovine balantidiasis recorded in this study was found lower than the findings of Christopher and Sudharshana (1972) who reported 68\% efficacy of metranidazole against balantidiasis in cattle and buffaloes. However, this variation of efficacy rate might be due to variation of dose and level of burden of the parasites. 


\section{Efficacy of fenbendazole against gastro-intestinal nematodiasis}

A single oral dose of fenbendazole (Peraclear ${ }^{\circledR}$, Techno Drugs) @ 7.5 mg / kg body weight was used to treat six calves affected with gastro-intestinal nematodiasis, of which 3 affected with toxocariasis, two with strongyloidosis and one with trichuriasis. Efficacy result of fenbendazole showed $100 \%$ reduction of faecal egg (epg) count in all the six treated calves (Table 2).

\section{Effects of anthelmintic treatment on milk production}

The effects of gastro-intestinal parasitosis on milk production in RCC are presented in Table 3. The milk production of apparently healthy RCC $(n=6)$ reared at the BAUDF ranged from 1.0 to $1.8 \mathrm{~kg}$ with an average 1.46 litre / animal / day (Table 3). The average milk production value (1.46 litre / day / cow) of RCC recorded in this study is comparatively lower than the findings of Habib et al. (2009) who reported $2 \mathrm{~kg} /$ animal /day milk production in RCC. This finding indicates that the RCC has the milk production potentiality similar to the zebu cattle. The milk production values of gastro-intestinal parasitosis affected RCC $(n=15)$ at pre-treatment stage ranged from 0.5 to 2.53 litre with an average of 1.41 litre / animal / day (Table 3). After 7 days of postanthelmintic treatment, the milk production values ranged from 0.8 to 3.23 liter with an average of 1.73 liter / animal / day (Table 3). It appears from the milk production results that the anthelmintic treatment caused to increase milk yield range from 0.06 to 0.73 with an average of 0.32 litre / animal / day (Table 3). It also indicates from the Table 3 that the overall 4.79 litre increased milk yield $(n=15)$ at day 7 post-treatment (Table 3). These findings are in conformity with the findings of Islam et al. (2005) who reported $6-40 \%$ increased milk yield following anthelmintic treatment in milch cows.

Table 3. Effects of gastro-intestinal parasitosis and anthelmintic treatment on milk production in lactating Red Chittagong cows

\begin{tabular}{|c|c|c|c|c|c|c|c|c|}
\hline \multirow{3}{*}{$\begin{array}{l}\text { S/ Status of } \\
\mathrm{N} \text { lactating } \\
\text { cows }\end{array}$} & \multirow{3}{*}{$\begin{array}{l}\text { No. of } \\
\text { cows } \\
\text { used }\end{array}$} & \multicolumn{7}{|c|}{ Milk production (liter / day) } \\
\hline & & \multicolumn{2}{|l|}{ Pre-treatment } & \multicolumn{2}{|l|}{ Post-treatment } & \multicolumn{3}{|c|}{ Difference } \\
\hline & & Total Range & Mean & Total Range & Mean & Total & Range & Mean \\
\hline (1) GI parasitosis & 15 & $21.130 .5-2.53$ & 1.41 & $25.920 .80-3.231 .73$ & & .79 & $-0.7+0.3$ & \\
\hline (2) Healthy control & 06 & $08.801 .0-1.80$ & 1.46 & $08.801 .00-1.801 .46$ & - & - & - & \\
\hline
\end{tabular}

\section{REFERENCES}

1. Alam MGS, Rahman A and Sen MM (1979). Balantidiasis in cattle. Bangladesh Veterinary Journal 13 : 39-42.

2. Christopher J and Sudharshana T (1972). Treatment of balantidiosis in cattle. Orissa Veterinary Journal 7 : 121-122.

3. Fikru R, Teshale S, Reta D and Yosef K (2006). Epidemiology of gastro-intestinal parasites of ruminants in western opomia Ethiopia. International Journal of Applied Research in Veterinary Medicine 4 : 51-57.

4. Georgiev B and Gruev A (1979). Effectiveness of levamisole and oxyclozanide in paramphistomiasis in sheep and cattle. Veterinary Medicine Nauki $16: 45$ - 51

5. Habib MA, Hossain MS and Bhuiyan AKFH (2009). Impact of urea-based diets on production of Red Chittagong cattle. Bangladesh Veterinarian $26: 74-79$.

6. Hann C and Bekure S (1991). Animal health services in sub-Saharan Africa: Initial experiences with new approaches. Technical Paper No. 134, World Bank, Washington, DC, USA, pp. 49.

7. Huque AKMF, Islam MR, Khan M, Sarder GC and Talukder MRI (1998). Study of incidence and comparative therapeutic response of various drugs against clinical balantidiosis in cattle. Progressive Agriculture 9 : 59-62.

8. Islam MA and Samad MA (1989). Efficacy of commercial fasciolicides against mixed infection of fascioliasis and amphistomiasis in cattle. Bangladesh Veterinarian $6: 27-32$.

9. Islam N, Awal MA, Islam MS, Sobhan MA and Rahman MM (2005). Efficacy of levamisole and triclabendazole against gastro-intestinal nematodes and trematodes in crossbred cows. Indian Journal of Veterinary Medicine $25: 24-27$.

10. Mufti MMR, Mostari MP. Deb GK, Nahar K and Huqye KS (2009). Genetic diversity of Red Chittagong cattle using randomly amplified polymorphic DNA markers. American Journal of Animal and Veterinary Science 4 : 1-5. 


\section{M. Rahman and M. A. Samad}

11. Nooruddin M, Baki MA and Das JG (1987). Clinico-pathological studies of an outbreak of trichuriasis in cow calves. Indian Journal of Veterinary Medicine $7: 116-119$.

12. Rabeya T, Bhuiyan AKFH, Habib MA and Hossain MS (2009). Phenotypic and genetic parameters for growth traits in Red Chittagong cattle of Bangladesh. Journal of Bangladesh Agricultural University 7 : 265-271.

13. Rahman MM and Samad MA (2008). Prevalence of bovine tuberculosis and its effects on milk production in Red Chittagong cattle. Bangladesh Journal of Veterinary Medicine $6: 175-178$.

14. Samad MA (2000). An overview of livestock research reports published during the twentieth century in Bangladesh. Bangladesh Veterinary Journal 34 : 53- 149.

15. Samad MA (2001). Epidemiological studies on gastro-intestinal parasitosis in calves under traditional management in Bangladesh. Bangladesh Veterinary Journal 35 : 9-18.

16. Samad MA (2008). Animal Husbandry and Veterinary Science. Volume 2, $1^{\text {st }}$ Pub, LEP Publication No. 11, BAU Campus, Mymensingh.

17. Siddiki AZ, Uddin MB, Hasan MB, Hossain MF, Rahman MM, Das BC, Sarker MS and Hossain MA (2010). Coproscopic and haematological approaches to determine the prevalence of helminthiasis and protozoan diseases of Red Chittagong cattle breed in Bangladesh. Pakistan Veterinary Journal 30 : 1-6.

18. Soulsby EJL (1986). Helminths, Arthropods and Protozoa of Domestic Animals. $7^{\text {th }}$ edn., ELBS, Bailler Tindal, London.

19. Steel RGD and Torrie JH (1980). Principles and Procedures of Statistics. $2^{\text {nd }}$ edn., McGraw Hill Book Company, Inc., London. 